\title{
GONAD CHARACTERIZATION AND REPRODUCTIVE CYCLE OF Collisella subrugosa (ORBIGNY, 1846) (GASTROPODA: ACMAEIDAE) IN THE NORTHEASTERN BRAZIL
}

\author{
ROCHA-BARREIRA, C. A. \\ Instituto de Ciências do Mar/Universidade Federal do Ceará, Av. Abolição, 3207, Praia do Meireles, \\ CEP 60165-082, Fortaleza, Ceará, Brazil \\ Correspondence to: Cristina de Almeida Rocha-Barreira, Instituto de Ciências do Mar/UFC, Laboratório de \\ Zoobentos, Av. Abolição, 3207, Meireles, CEP 60165-082, Fortaleza, Ceará, e-mail: cristina@labomar.ufc.br \\ Received July 23, 2001 - Accepted November 13, 2001 - Distributed November 30, 2002
}

(With 9 figures)

\begin{abstract}
Gonad characteristics and reproductive cycle in the acmaeid Collisella subrugosa from Northeastern Brazil were investigated. The individuals were collected monthly from February 1993 to April 1994 at Farol do Mucuripe Beach, Fortaleza, Ceará, Brazil. There is no external characteristic on the shell and the soft body structures except the gonad that allows sex differenciation. The gonad of limpet Collisella subrugosa showned four stages (1) "partially ripe", (2) "ripe", (3) "partially spawned" and (4) "spawned", stages. The reproductive cycle is continous, with the maturation and spawning running parallelly in this population. The temperature was constant during the study period and it did not seem to be important to induce the spawning. The salinity had a weak negative correlation with the spawn process.
\end{abstract}

Key words: reproductive cicle, histology, Collisella subrugosa.

\section{RESUMO}

\section{Caracterização da gônada e ciclo reprodutivo de Collisella subrugosa (Gastropoda: Acmaeidae) no Nordeste do Brasil}

As características da gônada e o ciclo reprodutivo de uma população de Collisella subrugosa foram estudados. Os indivíduos foram coletados mensalmente de fevereiro de 1993 a abril de 1994, na Praia do Farol do Mucuripe, Fortaleza, Ceará, Brasil. Não foi evidenciada nenhuma característica da concha e de outras estruturas da parte mole que permitisse identificar o sexo dos animais, exceto a gônada. A gônada de Collisella subrugosa apresentou as seguintes fases: (1) "parcialmente madura"; (2) "madura"; (3) "parcialmente esvaziada; e (4) "esvaziada". A reprodução é contínua, com a maturação e a eliminação de gametas ocorrendo paralelamente dentro da população. A temperatura mantevese constante no período de estudo e não pareceu exercer influência no processo de eliminação dos gametas. A salinidade apresentou correlação negativa fraca no período de desova.

Palavras-chave: ciclo reprodutivo, histologia, Collisella subrugosa.

\section{INTRODUCTION}

Limpets are numerically dominant in the macrobenthos of many intertidal rocky shore communites (Nui et al., 1992). As grazer on algae and a food source for carnivorous animals, they play an important role toward the energy transfer in the energy flow of the intertidal rocky shore community (Hawkins \& Hartnoll, 1978). Therefore, they influence the structure, composition and growth of some algae species. These animals have dynamic characteristics and life history (Creese, 
1981) that give important information about its ecology and biology a great value for any rocky intertidal communites structure analysis.

Collisella subrugosa is distributed throughout the whole Brazilian coast, from Ceará to Rio Grande do Sul (Rios, 1994). It is eurithopic and lives in intermediate range in the rocky shore.

Although there are many studies about the life history of Patelloidea, few studies were done with the brazilian species (Righi, 1966; Matthews-Cascon et al., 1990). The reproductive system in the patelloideans is very simple, consisting of the gonad and a short gonoduct leading into the right nephridium (Hyman, 1967). There is no external sexual dimorphism in patelloideans and sexes are defined through gonad examination. The present study had three aims: (1) to study gonadal external morphology, (2) to determinate the gonadal macroscopic characters that indicate the sexes and reproductive development stages, and (3) to describe the gonadal development stages through histological studies.

\section{MATERIALS AND METHODS}

About 100 individuals of different sizes were collected monthly from February 1993 to April 1994 along the intertidal rocky shore, during low tide, at Farol do Mucuripe Beach, Fortaleza, Ceará, Brazil (Fig. 1). The animals were maintained in an aerated aquarium for 48 hours in laboratory. After that, dissection and observations were made using a stereoscopic microscope.

Enviromnental parameters, such as temperature, salinity and rainfall were registred.

The sex and the gonadal stages were identified based on macroscopy characteristics, such as colour, texture, transparence and enlargement, following the methodology of previous studies (Orton et al., 1956; Fritchman, 1961; Seapy, 1966; Rao, 1973; Branch, 1974; Niu \& Fuji, 1989).

A total of 1,100 individuals were examined, and 135 individuals were taken to histological studies, in order to confirm their gonadal stage.

Immediatelly after removal, the visceral mass was fixed in Navaschin solution for 10 hours, and then dehydrated in a graded series of ethanol, cleared in xylen and embedded in wax. The whole soft body was cut into 5-7 $\mu \mathrm{m}$ cross-sections, and stained with Harris' hematoxilin followed by $1 \%$ aqueaus eosin. Germ cells were examinated according to early studies performed by Rocha (1995).

\section{RESULTS}

\section{Enviromnental parameters}

The rain fall values and water salinity registred for the Farol do Mucuripie Beach (Fortaleza, Ceará) during the study are shown in figure 2. Sea water, air and rock temperature were constant during this study (Fig. 3).

\section{External gonad morphology characterization}

According to the present observations, there are no shell nor soft body structures to differenciate sex characters, except the gonads. All the observed males did not have a copulatory organ. Thus, the sexes were only separated through the gonadal characteristcs. Compared to other patelloideans, Collisella subrugosa has a very simple reproductive system, with only an oval left gonad, that opens itself into the right nephridium.

\section{Male gonad (Fig. 4a)}

The follicles borders are dark brown, clearly defined and disposed side by side similar to a labyrinth. When the gonad is ripe, the follicles are so full with the cream white spermatic fluid, that they become connected with each other by themselves. According to developmental stage, the follicles show different diameters.

\section{Female gonad (Fig. 4b)}

The female gonad is light green and has a granulous appearance. Its structure is less compacted than the male gonad, mainly when it is not ripe. The follicle borders can not be distinguished, independently of its developmental stage.

The oocytes look like little light green granules and some red spots might appear when the gonad is ripe. The ripe gonad is very compacted, causing in oocytes loss of circular shape. When the gametes were almost completely spawned, some spaces could be observed in the gonad, between the remaining oocytes and the gonad changes to dark green colour.

\section{Gonadal stages characterization}

With the present observation of the gonadal external morphology of both sexes, and the analysis of their gonadal tissues, four developmental stages can be distinguished in Collisella subrugosa: (1) "partially ripe"; (2) "ripe"; (3) "partially spawned"; and (4) "spawned". 


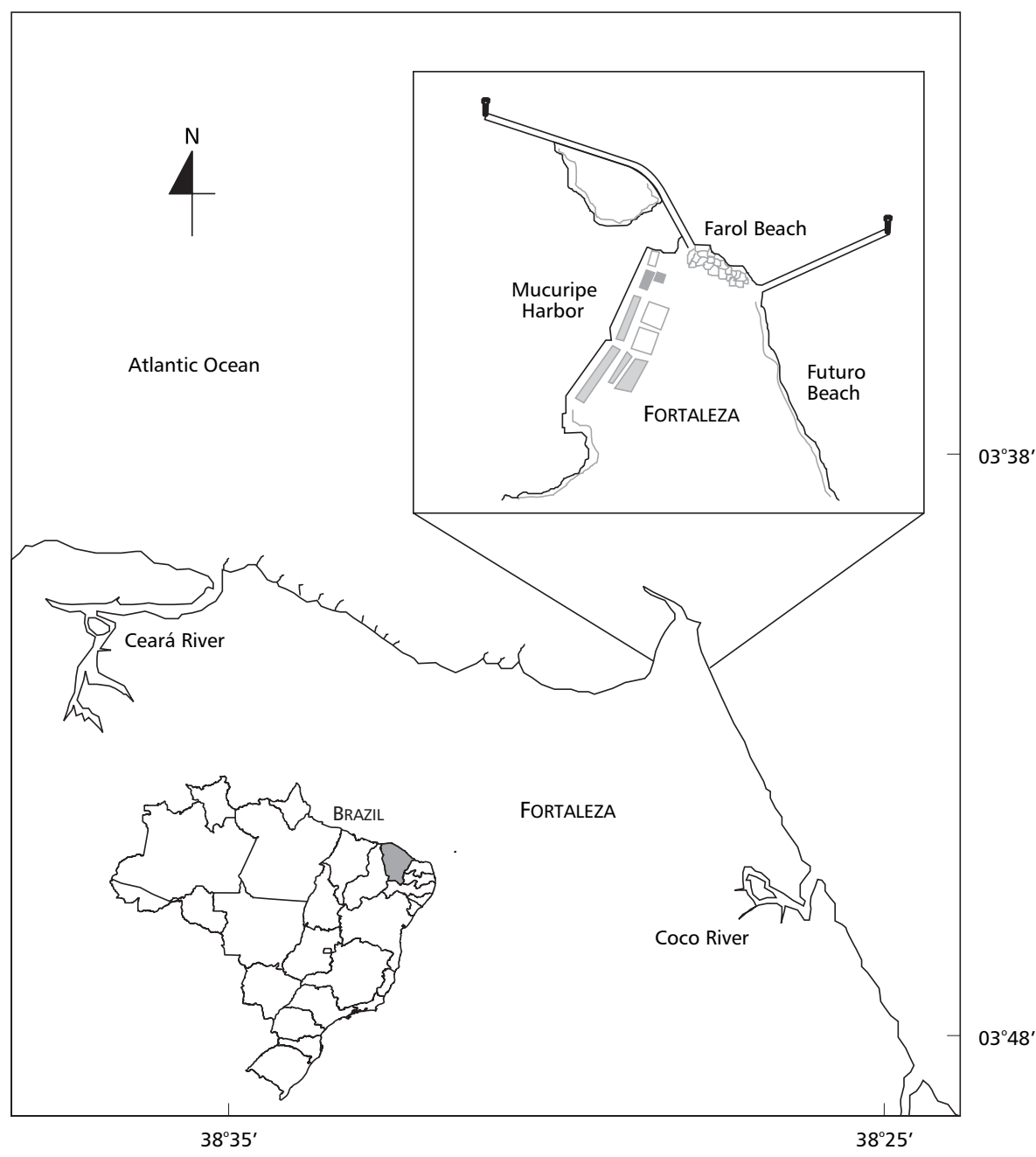

Fig. 1 - Map of the study area, Farol do Mucuripe Beach, Fortaleza, Ceará, Brazil.

It is important to point out that these stages are not tight, the spawning can always occur when there is a great amount of ripe germ cells.

A conspicuous variance in gonad colour in the developmental stages were not observed.

"Partially ripe" stage (Figs. 5a, 6a, 7a, 8a)

The germ cells divide and differenciate themselves to produce the ripe gametes. The gonad shows a tendency to occupy all of the ventral region of the visceral mass, when it reaches the ripe stage.
The follicles were clearly defined, mainly in males. They were narrow and had little spermatic liquid within. The inter-follicular space was large and dark brown. The oocytes are small in females and scattered in the gonad surface. The space between oocytes is light green.The walls of gonadal follicles became thicker and the follicles became progressively larger and the intra-follicular space reduced.

The spermatogonia and spermatocytes are clustered close to the follicular border and the spermatids and spermatozoa lay in the central area of the gonadal follicles. 


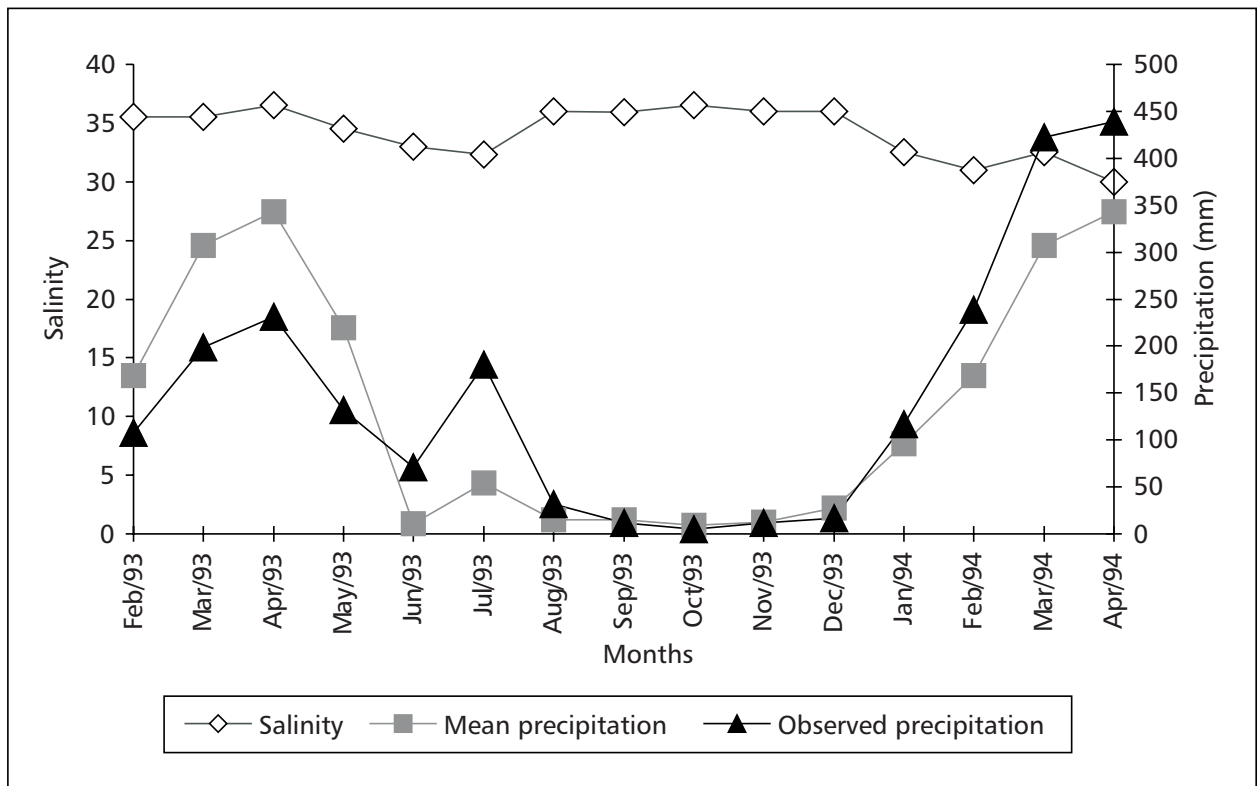

Fig. 2 - Precipitation values at Fortaleza (Ceará, Brazil) and the salinity during the study period at Farol do Mucuripe Beach.

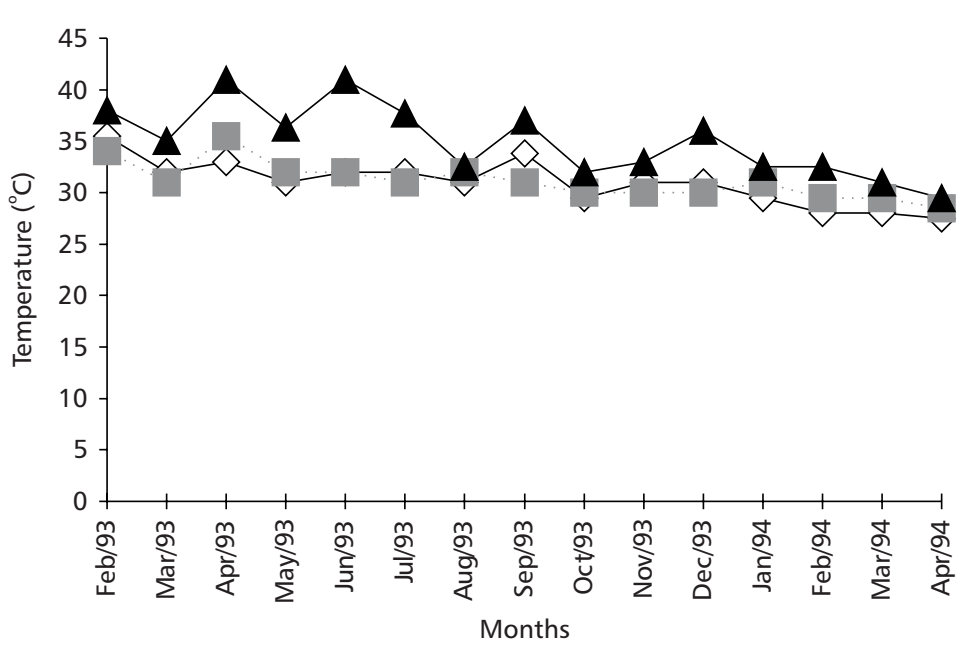

$\multimap$ Air $\cdots$ Sea water $\quad \longrightarrow$ Rock

Fig. 3 - Sea water, air and rock temperature at Farol do Mucuripe Beach during the study period. 

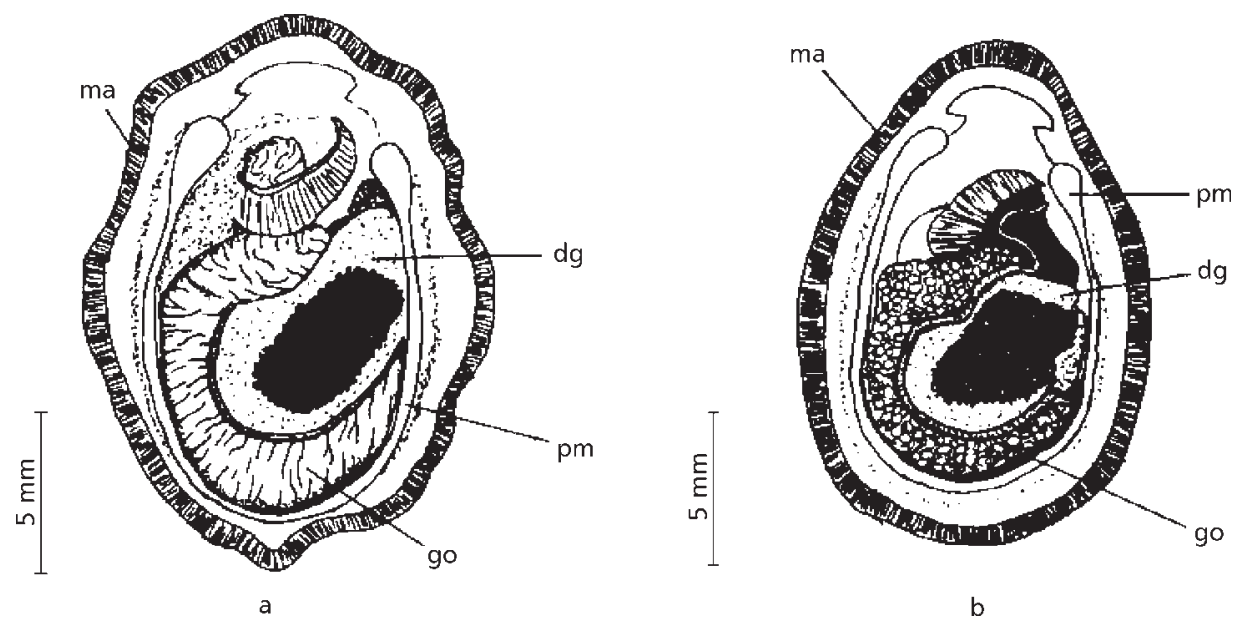

Fig. 4 - Diagramatic representation of the Collisella subrugosa dorsal view male (a) and female (b) soft bodies. dg: digestive gland, go: gonad, ma: mantle, pm: pedal muscle.

The female gonadal follicles are narrow and have a delicate connective membrane. The connective tissue cells are elongated with conspicous nuclei. Many oogonia, often clustered in nest, and previtellogenic oocytes were next to the follicular walls. The vitellogenic and ripe oocytes were not common in this stage.

\section{“Ripe" stage (Figs. 5b, 6b, 7b, 8b)}

The gonad is full and cover all of the ventral space within the visceral area. This gonad produces considerable pressure on the other visceral mass structures, mostly on the digestive gland. The gonad colour observed on the "partially ripe" stage is the same, however, the male gonad follicles were uniformly opaque and reddish spots in surface gonad were observed in some females. The male follicles were completely filled with white spermatic fluid, which were so filled that they became joined.

The ripe male gonad has thin walls of gonadal follicles with little intra and inter-follicular spaces. A great deal of spermatozoa was free in the follicles central area and scattered in the abundant spermatic fluid. These spermatozoa often appeared side by side with their flagella (tail) turned up to the follicles center. A great amount of spermatids and fewer spermatocytes I and II were observed in this stage. The spermatogonia were uncommon.

The oocytes are large and seemed to be in very tight clusters in females, so tight that the individual oocytes did not show their normal spherical shape.

The ripe female gonad is mainly composed of many vitellogenic and ripe oocytes. These cells were large and filled the follicles totally or partially. There were no spaces inside and outside the folicles. Some oogonia and previtellogenic oocytes were found close to the follicles borders.

“Partially spawned" stage (Figs. 5c, 6c, 7c, 8c)

This stage is very similar to "partially ripe" stage mainly in males. However, although the follicles were narrow, they had less spermatic fluid than the "partially ripe" stage.

The spermatozoa were divided into several small groups and many spaces were also observed in the male gonad. The follicular walls of the gonad were thin and composed of some spermatogonia and spermatocytes. The ripe and vitellogenic oocytes were separated from each other and several spaces were observed. Hence, very few oogonia, basophilic and previtellogenic oocytes are visualized. 
"Spawned" stage (Figs. 5d, 6d, 7d, 8d)

This stage was very well defined in females, with very reduced dark green gonad containing few oocytes. This stage was not so evident in male gonads. The follicles were narrow and there were few spermatozoa. Some spermatocytes could be observed next to the follicle borders and atresic areas in the lumen. The follicular walls become thickened and are formed by new germ cells and primary connective tissues. In the female gonad a large interfollicular space and a great decrease in the amount of ripe and vitellogenic oocytes can be observed. Some oogonia and previtellogenic oocytes groups were present close to the borders. Randomly atresic areas were observed in the follicles.

\section{Gonad stage frequency distribution}

The majority of male and female gonads observed during February to June 1993 were "partially ripe" or "ripe". There was a spawning period in July 1993. A new maturation period was observed between August to February 1994 and another spawning period was observed in March 1994 (Fig. 9).
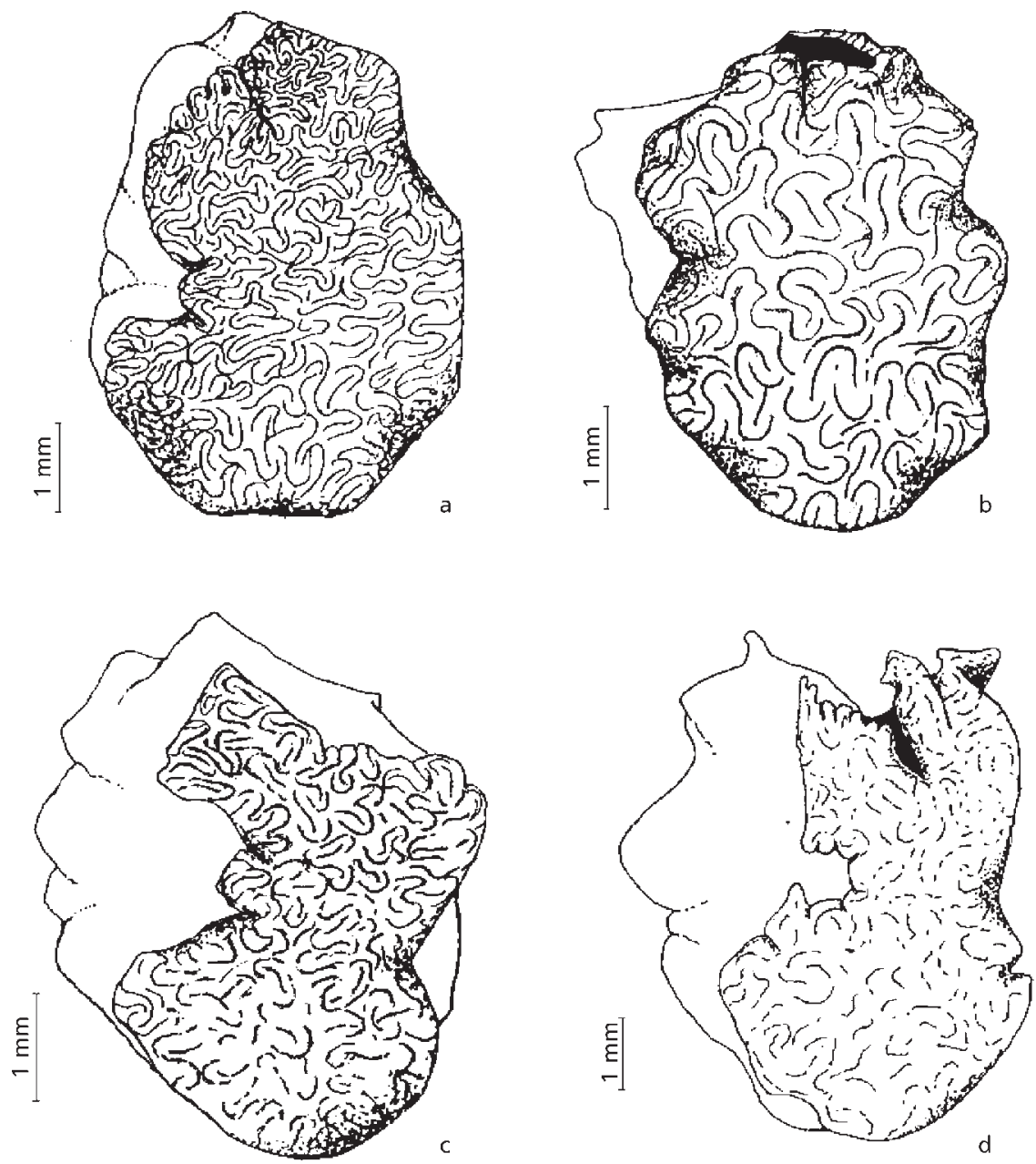

Fig. 5 - Diagramatic representation of progressive male gonad development: (a) partially ripe, (b) ripe, (c) partially spawned, (d) spawned. 

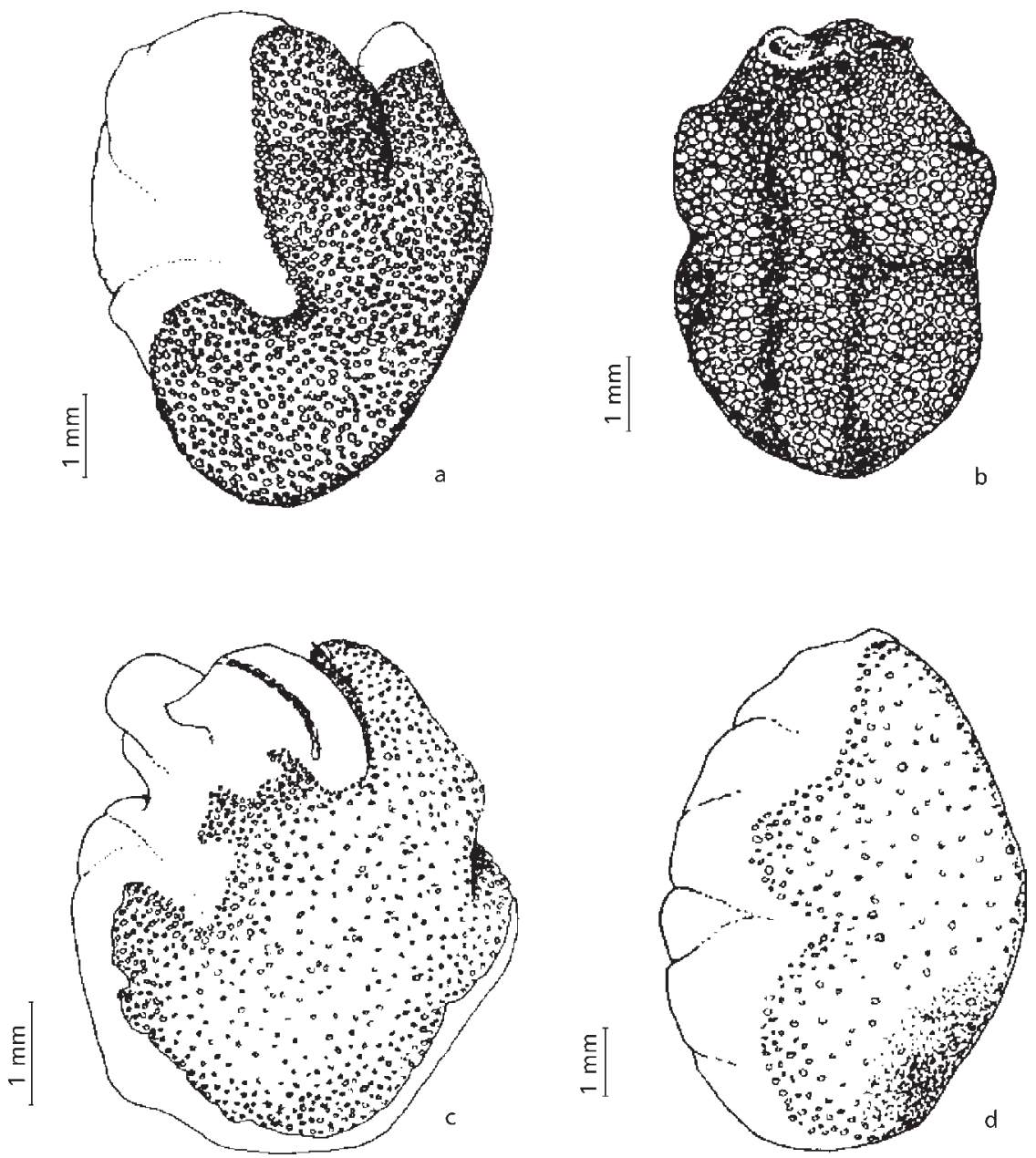

Fig. 6 - Diagramatic representation of progressive female gonad development: (a) partially ripe, (b) ripe, (c) partially spawned, (d) spawned.

These results were compared with abiotic parameters (temperature, salinity and precipitation). Only salinity exhibited $41 \%$ negative correlation with the spawn. There was no significance influence of the abiotic parameters under Collisella subrugosa reproductive cycle in this region.

\section{DISCUSSION}

The comparative analysis between the observations of the external and microscopic morphology of Collisella subrugosa gonad evidenced close correlation between the external characteristics and the cellular changes into the gonad during the maturation process.

The gradual increase in the gonad size and thickness in both sexes results from germ cells proliferation in the gonadal tissue. The intra and inter-follicular spaces were observed in both sex gonads at the begining of the spawn.

The oocytes were dispersed on the female gonadal surface and the male follicles became narrow and with little spermatic fluid. Frichtman (1961) called this follicular condition as "flacid". 

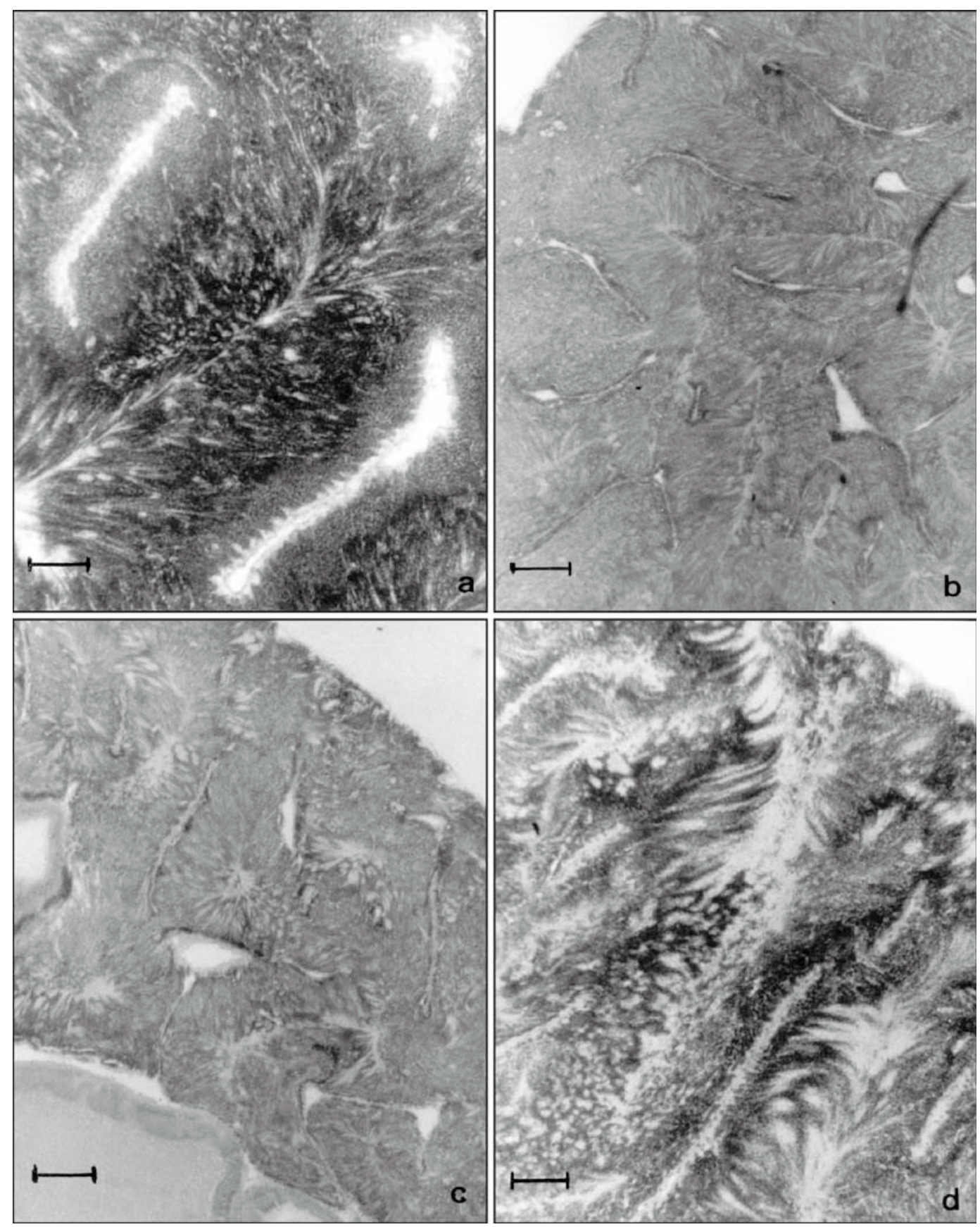

Fig. 7 - Histological microphotographs showing the Collisella subrugosa male gonad in different stages: (a) partially ripe, (b) ripe, (c) partially spawned, (d) spawned. 

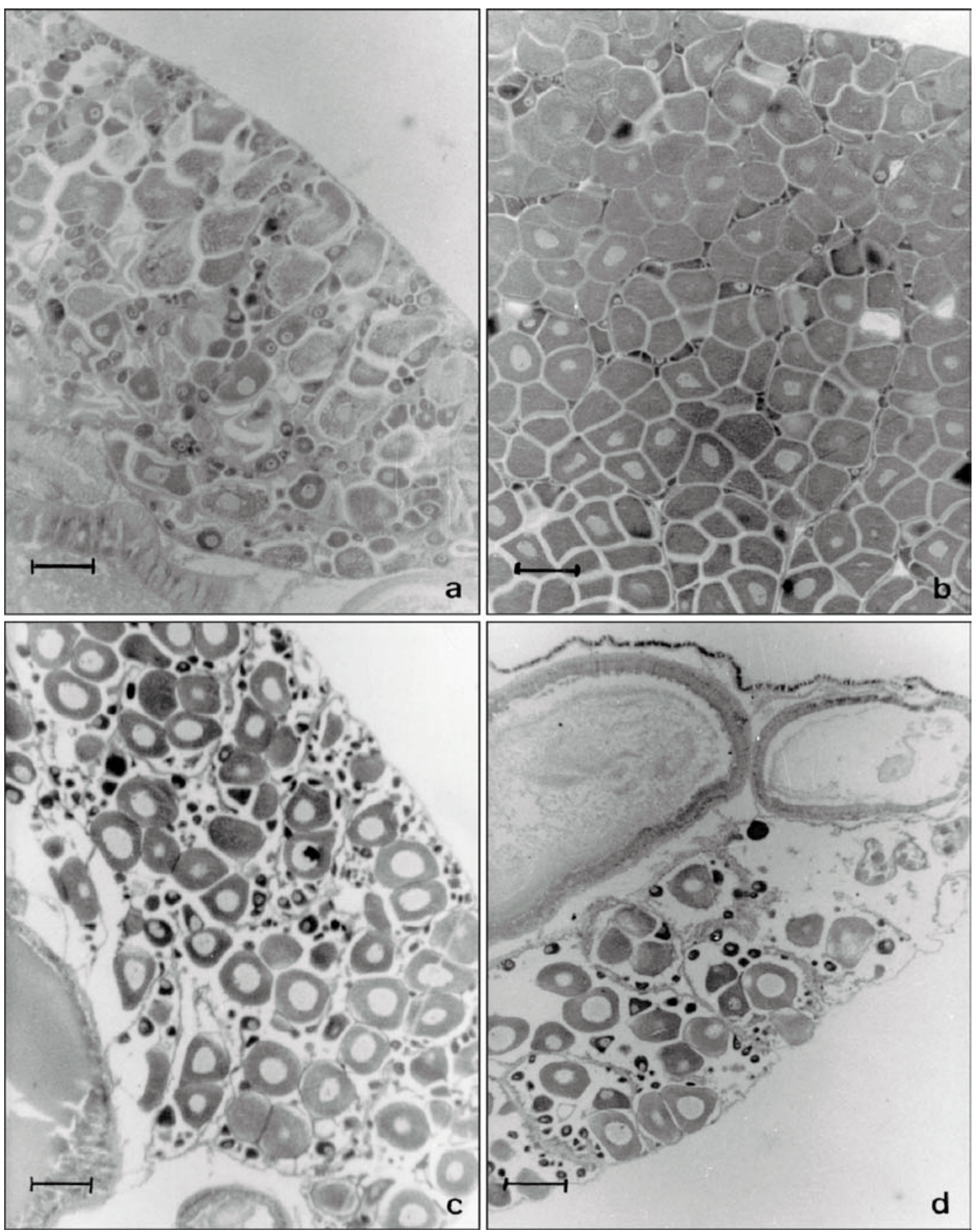

Fig. 8 - Histological microphotographs showing the Collisella subrugosa female gonad in different stages: (a) partially ripe, (b) ripe, (c) partially spawned, (d) spawned. 


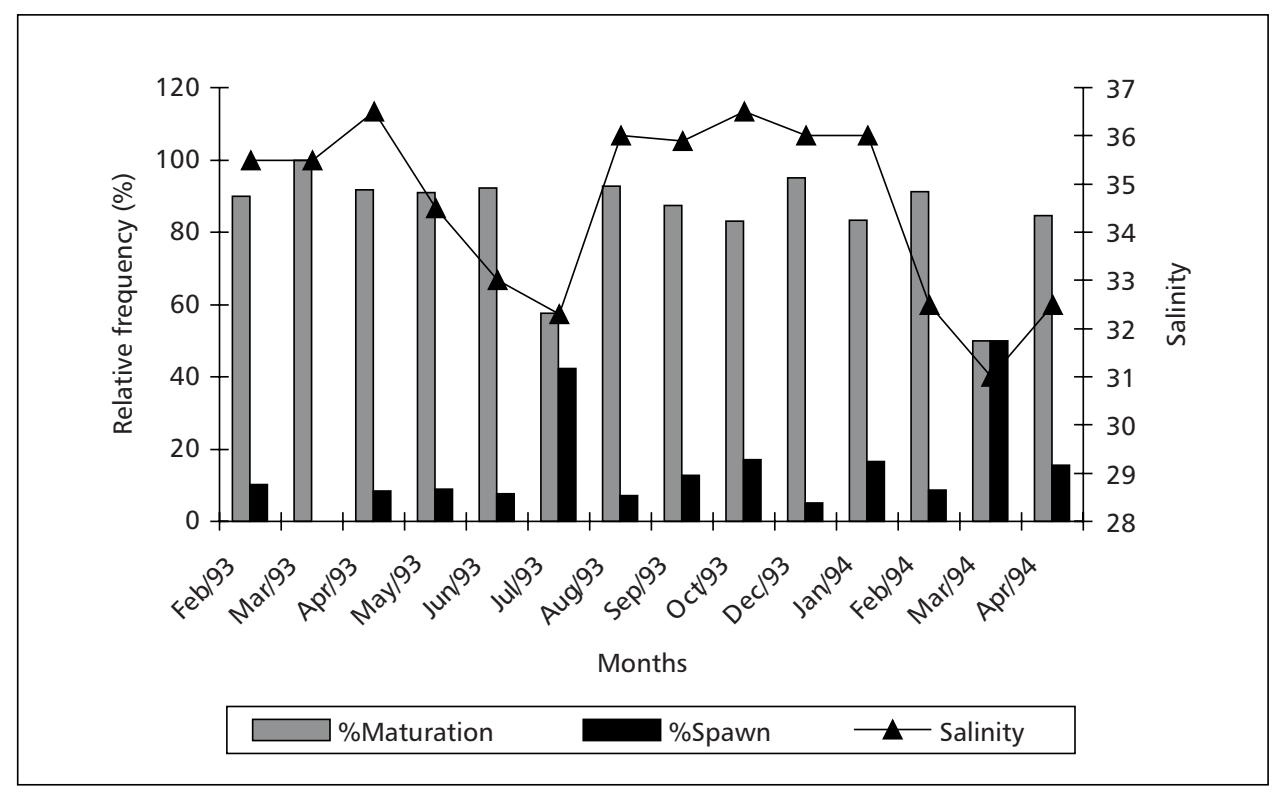

Fig. 9 - Maturation (partially ripe and ripe stages) and spawned (partially spawned and spawned) periods of Collisella subrugosa in relation with observed salinity.

According to Giese \& Pearse (1977), the stability of external factors characterize some regions, where marine animals have continuos sexual cycles thoughout the year and where the external factores did not affect reproduction at a certain time of the year. These ideas were confirmed to this studied tropical population.

Rao (1973) confirmed that temperature and salinity seem to have no marked influence in inducing spawning in Cellana radiata, however he noticed the absence of spawning during the months when the tempature was high or when the salinity was low. This phenomenon suggests that high temperature and low salinity are probably unfavourable to spawning.

Sea water, rocky and air temperatures, and salinity were constant during this study and probably do not exhibit any important change to induce the spawning on this Collisella subrugosa population.

Acknowledgments - The author wishes to express her gratitude to Prof. Dr. Henry Ramos Matthews for advising this research. Her special thanks to Biologist Wilson Franklin Júnior for his help in the field collecting. She is grateful to Profa. Dra. Tereza Cristina Vasconcelos Gesteira for her help in the histological studies and for reading this manuscript, and she also give her thanks to Mr. José Alberto Almeida Júnior for the drawings that illustrate this paper and Profa. Dra. Helena Matthews Cascon for reading this manuscript.

\section{REFERENCES}

BRANCH, G. M., 1974, The ecology of Patella Linnaeus from the Cape Peninsula, South Africa. II. Reproductive cycles. Trans. Roy. Soc. S. Afr., 41(2): 111-158.

CREESE, R. G., 1981, Patterns of growth, logevity and recruitment of intertidal limpets in New South Wales. $J$. Exp. Mar. Biol. Ecol., 51: 145-171.

FRITCHMAN, H. K., 1961, A study of the reproductive cycle in the California Acmaeidae (Gastropoda). Part I. Veliger, 3(3): 95-101.

GIESE, A. C. \& PEARSE, J. S., 1974, Introduction: General principles. In: A. C. Giese \& J. S. Pearse (ed.), Reproduction of marine invertebrates. Academic Press, New York, 469p.

HAWKINS, S. J. \& HARTNOLL, R. G., 1978, Grazing of intertidal algae by marine invertebrates. Oceanogr. Mar. Biol. Ann. Rev., 21: 195-282. 
HYMAN, L. H., 1967, The invertebrates. VI. Mollusca I Aplacophora, Polyplacophora, Monoplacophora, Gastropoda. The coelomate Bilateria. McGraw-Hill Book Company, New York, 795p.

MATTHEWS-CASCON, H., SANTIAGO, M. E., MARTINS, I X. \& MATTHEWS, H. R., 1990, Predação pelo crustáceo Pachygrapsus tranversus (Gibbes, 1850) sobre o molusco Acmaea subrugosa (Orbigny, 1846). In: Anais da Sociedade Nordestina de Zoologia. Ed. da UFAL, Maceió, pp. 203-210.

NIU, C. \& FUJI, A., 1989, Gametogenesis and reproductive cycle of the limpet Collisella herlodi (Dunker, 1861) Bull. Fac. Fish. Hokkaido Univ., 40(4): 214-217.

NUI, C., NAKAO, S. \& GOSHIMA, S., 1992, Grownth, population age structure and mortality of the limpet Collisella subrugosa (Dunker, 1861) (Gastropoda: Acmaeidae) in an intertidal rocky shore, in Southern Hokkaido. Bull. Japan. Soc. Sci. Fish., 58(8): 1405-1410.

ORTON, J. H., SOUTHWARD, A. J. \& DODD, J. M., 1956 Studies on the biology of limpets II. The breeding of Patella vulgata L. in Britain. J. Mar. Biol. Ass. U. K., 35: 149-176.
RAO, M. B., 1973, Sex phenomenon and reproductive cycle in the limpet Cellana radiata (Born) (Gastropoda: Prosobranchia). J. Exp. Mar. Biol. Ecol., 12: 263-273.

RIGHI, G., 1966, On the brazilian species in the Acmaea subrugosa complex (Gastropoda: Prosobranchia: Patellacea). Malacologia, 4(2): 239-295.

RIOS, E. C., 1994, Seashells of Brazil. 2. ed. Ed. Fundação Universidade do Rio Grande, Rio Grande, 331p.

ROCHA, C. A., 1995, Estudo da proporção sexual e ciclo reprodutivo de Collisella subrugosa (Orbigny, 1846) (Mollusca: Gastropoda: Acmaeidae) no Nordeste do Brasil. M.Sc. Thesis, Universidade Federal da Paraíba, João Pessoa, Brasil.

SEAPY, R. R., 1966, Reproduction and growth in the file limpet Acmaea limatula Carpenter, 1864 (Mollusca: Gastropoda). Veliger, 8(4): 300-310. 